${ }^{1}$ VILCHES, A., ${ }^{2}$ GIL-PEREZ, D., ${ }^{3}$ EDWARDS, M., ${ }^{4}$ PRAIA, J.

\title{
SCIENCE TEACHERS' PERCEPTIONS OF THE CURRENT SITUATION OF PLANETARY EMERGENCY
}

\author{
${ }^{1,2,3}$ Universitat de València, Spain, ${ }^{4}$ Universidade de Porto, Portugal
}

\begin{abstract}
During the United Nations Conference on Environment and Development held in Rio in 1992 educators of every subject were asked to contribute to public awareness and understanding of the problems and challenges related to our planet's future, in order to make possible citizens' participation in well grounded decision-making. The purpose of our contribution is to analyse what science teachers' perceptions are, because without correct teacher perception of the planetary crisis and its possible solutions, we can't expect their effective implication in this dimension of education.
\end{abstract}

\section{BACKGROUND, AIMS AND FRAMEWORK}

Until the second half of the 20th Century, our planet seemed very large, practically without limits, and the effects of human activities remained locally compartmentalised (Fien 1995). But these compartments have begun to dissolve during the last decades, and many problems (greenhouse effect, ozone depletion, acid rain...) have acquired a global dimension (Bybee 1991; Orr 1995). The "state of the world" has become, for this reason, an object of growing concern. This is the reason why educators are being asked to contribute to public awareness and understanding of the problems and challenges related to our planet's future, in order to make possible citizens' participation in well grounded decision-making (United Nations 1992).

Our hypothesis is that, in spite of such dramatic appeals, attention paid by science teachers to the state of the world is still very poor and constitutes a serious missing dimension in science teachers education and, more generally, in science education research and innovation (Gayford 1993; Gil-Pérez 2000). Our purpose is, very precisely, to analyse what science teachers' perceptions are, because without correct teacher perception of the planetary crisis and its possible solutions, we can't expect their effective implication in this dimension of education. This analysis demands, firstly, to clarify what we understand by a correct view of the state of the world.

If we want to understand correctly the current situation of planetary emergency and how to act upon it, it seems necessary to go beyond the consideration of some concrete or local environmental problems. As Tilbury (1995) signals, "environmental and development problems are not solely caused by physical and biological factors" and "an understanding of the parts played by aesthetic, social,

[Editor(s) here] (ed.), [Book Titlen here], $1-8$.

(C) в а Kluwer Academic Publishers. Printed in the Netherlands. 
economic, political, historical and cultural elements is required". We need to construct a global picture of the state of the world and study thoroughly the possible causes and remedies. With this aim:

- We have made an effort to take into account the contributions of different studies elaborated with an explicit global point of view, and very particularly the Worldwatch annual dossiers on the state of the world (Brown et al. 1984-2001);

- We have also analysed papers published on the subject in science education and environmental education journals;

- We have undertaken a Delphi study (Gil-Pérez 2000) implicating several dozens of science teachers of all levels and from different countries.

These studies have permitted us to construct a network (Table 1) which summarises the ensemble of related problems, causes and challenges that characterise, in our opinion, the state of the world (Gil-Pérez 2000).

\section{METHODS AND SAMPLES}

In order to find out to what extent teachers' conceptions on the state of the world respond to a correct perception of the problems to be faced and the measures to be adopted, we have conceived several experimental designs as, for instance:

- To pose an open question to teachers in training and in service, about "problems and challenges that humanity has to face", in order to see if they make reference to the different aspects that are relevant in this respect;

- To analyse the content of science textbooks (looking for any reference to the state of the world and its future);

- To analyse the content of papers published in science education journals (looking for researches related to the state of the world as, for instance, analyses of students' or teachers' conceptions).

The open question has already been proposed to wide samples of science teachers, in service and in training from Spain, Portugal and Latin America (Argentine, Brazil, Chile, Cuba, Mexico, Panama...) with a total of 327 teachers in service and 521 in training. On the other hand, we have analysed more than 300 Spanish science textbooks. Finally, we have analysed 9932 papers published between 1992 and 1998 in 31 science education journals.

The information collected with these different designs has been analysed using the network elaborated to summarise the ensemble of related problems, causes and challenges that characterise the state of the world (table 1). 
Table 1. Problems and challenges that characterise the present state and near future of the world

0) The main aim should be to lay the bases of a sustainable development .

This directs our attention towards an ensemble of interconnected aims and actions:

1) To put an end to socio-economic growth, guided by particular interests in the short term, that seriously damages the environment and is particularly dangerous for living beings

This economic growth produces, among other things, these particular problems:

1.1. A growing, disordered and speculative urbanisation

1.2. Environmental pollution and its consequences (greenhouse effect, acid rain, global climatic change...)

1.3. Depletion of natural resources (fossil energy resources, fertile soil, drinking water...)

1.4. Ecosystems degradation and destruction of biological diversity (cause of illness, ravenous hunger...)

1.5. Destruction, in particular, of cultural diversity

2) To put an end to the following causes (and, at the same time consequences) of an unsustainable socio-economic growth:

2.1. Over-consumption of "developed" societies and dominant groups .

2.2. Demographic explosion in a limited planet

2.3. Social inequalities between human groups

2.4. Conflicts and violence associated with these inequalities (military conflicts, Mafia's activities, speculation of transnational enterprises that escape any democratic control...)

3) To adopt positive measures in the following fields:

3.1. Political measures at the planetary level capable of promoting and controlling the necessary protection of social and physical environment, before the current degradation processes become irreversible

3.2. Educational measures to overcome the usual tendency to behave attending to particular interests in the short term, making possible changes in personal values and life style choices to promote solidarity

3.3. Technological measures to better satisfy human needs without damaging the environment, capable of favouring a sustainable development. This includes, for instance, the search for new energy sources, the improvement of efficiency in food production, the prevention of illness and catastrophes or the diminution and recycling of waste)

4) To associate the precedent measures with the need to universalise and enlarge human rights

4.1. Democratic civil rights (opinion, association...) for everybody as a condition sine qua non for citizens' decision-making about current and future environmental and social problems.

4.2. Economic, social and cultural rights (to a satisfactory job, to health, to education and culture...)

4.3. Right, in particular, to investigate any kind of subject (life's origin, genetic manipulation...) without ideological limitations, but with a social control that takes into consideration the social and environmental consequences and prevents the hasty application of non sufficiently tested technologies.

4.4. Solidarity rights (right to a healthy environment, right to peace and right to a sustainable development) 


\section{RESULTS}

The results obtained with the different samples of teachers are highly concordant and show a quite reductionist perception of the science education community about the state of the world, which is also reflected in science textbooks and in papers published in science education journals.

\subsection{References to sustainability}

When thinking about problems and challenges concerning the future of humanity, the basic aim signalled by experts is to lay as near as possible the bases of a sustainable development, that is to say, of a development that "meets the needs of the present without compromising the ability of future generations to meet their own needs" (World Commission on Environment and Development 1987). "Sustainability is the central unifying idea society most needs at this point of human history" (Bybee 1991).

From the evidence of our surveys, references to global considerations such as the idea of sustainable development are very rare: only $7.3 \%$ of the 327 science teachers in service and $4.1 \%$ of the 521 teachers in training make any references to sustainability.

But, how are we to move towards a sustainable society (or sustainable development)? Experts (United Nations 1992) refer to the necessity of putting an end to a series of interconnected facts, each one having a particular importance and deserving particular attention, but completely linked to the rest: none of them can be understood or treated without taking into account the whole ensemble. It is not enough, for instance, to criticise -as is usually done- environmental pollution and its consequences (greenhouse effect, acid rain...) or depletion of natural resources: there are other problems to be taken into account.

\subsection{Attention to the problems that affect our survival and their causes}

Quite high percentages of science teachers -both in service and in trainingsignal environmental pollution, depletion of natural resources and destruction of biological diversity among the main problems humanity has to face. On the contrary, there are few references to related problems such as growing and disordered urbanisation or the destruction of cultural diversity (less than $20 \%$ make any reference to these aspects). This very frequent omission is a clear example of the reductionism that characterises science teachers' views -and even environmental educators' views- about our planet's problems (Fien 1995).

The same reductionism appears in relation to the possible causes of the Earth's degradation: About $40 \%$ of science teachers denounce economic growth, guided by particular interests in the short term, as the foundation of the current degradation processes. This is a correct appreciation, according to the analyses of, for instance, the World Commission on Environment and Development or the Worldwatch Institute (Brown et al. 1984-2000). But these problems are intimately related to other phenomena that should be considered as well. Firstly, we draw attention to the over- 
consumption of so called "developed countries" and of dominant groups in each society (United Nations Development Program 1998). A consumption that keeps growing as if the Earth's capacities were infinite is indefensible (Folch 1998).

Secondly, it is necessary to halt the demographic explosion on a planet which has limited resources (Ehlrich and Ehlrich 1990). In a planet where, since the second half of the $20^{\text {th }}$ century, more human beings have been born than in the whole of humanity's history and where the present population would need the resources of three Earths to generalise the standard of living of the developed countries (United Nations 1992).

In short, over-consumption and demographic explosion determine an economic growth which is extremely corrosive of the physical and cultural environment. Astonishingly, in our survey science teachers do not seem to be aware of the importance of these two determining factors; only about $20 \%$ make any reference to demographic growth, and over-consumption is mentioned by less than $10 \%(!)$.

On the other hand, over-consumption in developed countries and demographic explosion in others provoke grave inequalities. Billions of fellow humans are scarcely able to survive in non-developed countries and there is the exclusion of wide segments of the "first world"... while a fifth of the human population offers its high-consumption model (United Nations Development Program 1997; Folch 1998). Extreme poverty in undeveloped countries, that is a consequence of the demographic explosion and of the imposition of particular interests and values (through military conflicts or through the activities and speculations of trans-national enterprises which seek to avoid any democratic control) lead inexorably to an unsustainable exploitation of natural resources, in a desperate attempt to pay back interest, satisfy external debts and gain some benefit. These inequalities and derived conflicts receive certain attention in the responses of our survey of science teachers (about $50 \%$ make reference to them). But, as we have already indicated, no relationship is established between these problems and over-consumption or demographic explosion. There seems to be a serious lack of understanding of the relevance of globalisation to the problems outlined.

\subsection{What positive measures can be adopted?}

A holistic approach to the state of the world demands more than diagnosing the problems; it is also necessary that teachers study the possible solutions to the described planetary crisis, in order to help their pupils to explore alternative approaches and to participate in actions aiming to favour particular alternatives. We can structure the different proposals made by researchers and institutions into the following three groups:

- Technological measures to better satisfy human needs without damaging the environment;

- Educational measures to make possible the necessary changes in personal values and life-style choices;

- Political measures at a planetary level to avoid the imposition of particular interests and values harmful for other people or future generations. 
About $30 \%$ of science teachers in service and $50 \%$ of science teachers in training refer to the need for these technological measures. Incidentally, this is one of the few aspects where we find strong differences between teachers in training and in service. Nevertheless, although technology has an important role to play, it is necessary to question the widespread and erroneous idea that the solution to the serious problems which humanity has to face today depends solely on a better knowledge and on more advanced technologies: options and dilemmas are essentially matters of ethics (Tilbury 1995). This conclusion directs us in part to the educational measures we have to consider.

About $60 \%$ of science teachers in service and $50 \%$ of science teachers in training signal the need for educational measures, in accordance with the recommendations of sustainability experts (United Nations 1992). The educational measures proposed to contribute to a sustainable society put the accent on global analyses and solidarity (Delors et al. 1996). We need an education that contributes to a correct perception of the state of the world and prepares citizens for decision-making, generating responsible attitudes and behaviours (Bybee 1991; Fien 1995; Tilbury 1995) oriented to the attainment of a culturally plural and physically sustainable development.

On the other hand, individual contributions can and must go beyond the private domain and extend to professional, social and political activities. It is necessary, in particular, that individual and collective actions avoid local or partial approaches and contemplate many-sided environmental questions (pollution, resources depletion...), and other related problems such as social inequalities and conflicts, from a planetary perspective. The ecologists slogan "to think globally and to act locally" has its limitations; we now know that it is also necessary to act globally as well, adopting political measures at a planetary level, capable of avoiding the imposition of particular interests and values harmful for other peoples or for future generations.

In short, a new world order is required, based on co-operation and solidarity, with institutions capable of avoiding the imposition of particular vested interests harmful to other people or to future generations (Folch 1998). Unfortunately, only about $20 \%$ of science teachers in training or in service contemplate the need for political measures to guarantee the defence of the environment and life on Earth.

The ensemble of measures just discussed, appears nowadays to be associated with the need to universalise human rights. The next section is dedicated to clarifying this relationship.

\subsection{Sustainable development and human rights}

It may seem strange to establish such a direct relationship between human rights and sustainable development. In fact, only $6 \%$ of teachers in service and in training consider that overcoming the current degradation processes and inequalities is a question of human rights. For this reason, we shall try to clarify what is understood nowadays by human rights, a concept that has been growing and now contemplates three "generations" of rights (Vercher 1998). 
We can refer, firstly, to democratic civil rights (opinion, association...) for everybody, without social, ethnic or gender limitations. They constitute a condition sine qua non for citizens' decision-making about current and future environmental and social problems (Folch 1998). They are known nowadays as "first generation human rights", because they have been the first rights to be demanded and obtained (not without conflicts and frequent violations) in a growing number of countries.

We refer, secondly, to economic, social and cultural rights or "second generation human rights" (Vercher 1998) as, among others, the right to a satisfying job; to an adequate dwelling; to appropriate nourishment; to health; to family planning and free enjoyment of sexuality (the only limitation being the freedom of others; to an education of quality, throughout one's life, without social, ethnic or gender limitations; to investigate any kind of subject (life's origin, genetic manipulation...) without ideological limitations but with a suitable degree of social control to prevent the hasty application of insufficiently tested technologies.

Finally, we refer to third-generation human rights, known as solidarity rights "because they tend to preserve the integrity of the whole population" (Vercher 1998). They incorporate the right to life in a suitable environment, the right to peace and the right to a sustainable development for all people and future generations.

The ensemble of these rights appears to be a requisite (and, at the same time, an objective) of a sustainable society; they are all interconnected. We cannot conceive, for instance, the interruption of the demographic explosion without the recognition of the right to family planning and free enjoyment of sexuality... and these are connected also to the right to education. In short, then, achieving sustainable development is synonymous with universalising human rights in its widest sense. Unfortunately, we notice, most science teachers in our survey did not make any reference to human rights: only $6 \%$ of teachers (both in service or in training) consider that overcoming the current degradation processes and inequalities is a question of human rights; references to democratic civil rights are made by less than $2 \%$ of science teachers and less than $7 \%$ refer to rights of solidarity; the only rights that are mentioned by a significant percentage of science teachers -about $10 \%$ - are socio-economic ones.

\section{CONCLUSIONS. A GLOBAL ANALYSIS OF THE RESULTS AND PERSPECTIVES}

Any attempt to face up to the problems that affect human survival should contemplate the ensemble of challenges that we have pointed out (table 1). We have already shown that high percentages of science teachers' perceptions (both in service and in training) about the state of our planet ignore each one of the aspects studied. In fact the mean of the aspects identified by teachers in service and in training is, respectively, 4.7 and 4.9 (from a total of 19). The similarly poor perceptions of both groups emphasises our finding that the concern for the state of the planet is a missing dimension in science education.

These results explain why we have referred to the state of the world as a missing dimension in science teachers' education. A dimension to be urgently incorporated. 
We have already begun to implement workshops to facilitate the study of these problems by science teachers (Gil-Pérez et al. 2000). The first results obtained are quite encouraging.

\section{REFERENCES}

Brown, L., R. et al. (1984-2001). The State of the World. New York: W.W. Norton.

Bybee, R.,W., (1991). Planet Earth in Crisis: How Should Science Educators Respond? The American Biology Teacher, 53(3), 146-153.

Delors, J. et al. (1996). L'Éducation: un Trésor Est Caché Dedans. UNESCO. Commission Internationale sur l'Education pour le vingt et unième siècle. Paris : Jacob O.

Ehlrich, P.,R. \& Ehlrich A.,H., (1990). The Population Explosion. London: Touchstone.

Fien, J., (1995). Teaching for a Sustainable World: the Environmental and Development Education Project for Teacher Education. Environmental Education Research, 1(1), 21-33.

Folch, R., (1998). Ambiente, Emoción y Ética. Barcelona: Ariel.

Gayford, C., (1993). Where Are We Now with Environment and Education? (Editorial) International Journal of Science Education, 15 (5), 471-472.

Gil-Pérez, D., (2000). The state of the world. A missing dimension in physics teacher education. In: Pinto, R. \& Surinach, S. (eds), Physics Teacher Education Beyond 2000. Paris: The Data Science Library.

Gil-Pérez, D., Vilches, A., Astaburuaga, A. \& Edwards, M., (2000). La Atención a la Situación del Mundo en la Educación de los Futuros Ciudadanos y Ciudadanas. Investigación en la Escuela, 40, 39-56.

Orr, D.,W., (1995). Educating for the Environment. Higher Education's Challenge of the Next Century. Change, May/June, 43-46.

Tilbury, D., (1995). Environmental Education for Sustainability: Defining the New Focus of Environmental Education in the 1990s. Environmental Education Research, 1(2), 195-212.

United Nations, (1992). UN Conference on Environmental and Development. Agenda 21 Rio Declaration, Forest Principles. Paris: Unesco.

United Nations Development Program, (1997). Human Development Report. Human Development to Eradicate Poverty. New York: Oxford University Press.

United Nations Development Program (1998) Human Development Report. Consumption for Human Development. New York: Oxford University Press.

Vercher, A., (1998). Derechos Humanos y Medio Ambiente. Claves de razón práctica, 84, 14-21.

World Commission on Environment and Development, (1987). Our Common Future. Oxford: Oxford University Press. 